\title{
Nutrient cycling in a microflagellate food chain: II. Population dynamics and carbon cycling*
}

\author{
David A. Caron ${ }^{1}$, Joel C. Goldman' ${ }^{2}$ O. Ketil Andersen ${ }^{2 * *}$ \& Mark R. Dennett ${ }^{2}$ \\ ${ }^{1}$ Lamont-Doherty Geological Observatory, Palisades, New York 10964, USA \\ ${ }^{2}$ Woods Hole Oceanographic Institution, Woods Hole, Massachusetts 02543, USA
}

\begin{abstract}
Carbon cycling in a 3-member food web containing a diatom (Phaeodactylum tricornutum), bacteria, and a herbivorous/bacterivorous microflagellate (Paraphysomonas imperforata) was examined. Ingestion of prey by the microflagellate was the primary mechanism for remineralization of particulate organic material. Approximately $65 \%$ of the particulate organic carbon (POC) initially present was lost over the course of the $8 \mathrm{~d}$ experiments in cultures containing microflagellates. No significant increase in remineralization was observed when bacteria were present. Bacteria were responsible for the uptake of dissolved organic carbon (DOC), but their overall contribution to carbon cycling was small relative to that of the microflagellate. Microflagellates incorporated diatom and bacterial biomass with equal efficiency $(44 \%)$ during exponential growth. Only $10 \%$ of the POC ingested by microflagellates was released as DOC while $10 \%$ was released as egested POC. The relatively high weight-specific respiration rate of the microflagellates $\left(\overline{\mathrm{X}}=2.67 \times 10^{-5} \mathrm{nl} \mathrm{O} \mathrm{O}_{2}\right.$ $\mu \mathrm{m}^{-3} \mathrm{~h}^{-1}$ ) coupled with their relatively small release of DOC indicates that herbivory by heterotrophic microflagellates may be a major mechanism for the regeneration of nutrients from living phytoplankton which circumvents bacterial decomposition.
\end{abstract}

\section{INTRODUCTION}

It is becoming increasingly apparent that heterotrophic microflagellates are the major consumers of bacteria in plankton communities (Haas \& Webb 1979, Fenchel 1982c, Linley et al. 1983, Davis \& Sieburth 1984). By repackaging bacterial biomass into cells accessible to filter-feeding zooplankton, these ubiquitous protozoa constitute a mechanism for returning energy lost to the detritus food chain, or 'microbial loop', back to the conventional phytoplanktoncopepod-fish food chain (Azam et al. 1983). This view of protozoan ecology emphasizes the role which phagotrophic microflagellates play in the conservation of energy and nutrients for use by higher trophic levels. However, the potential also exists that these predators constitute a 'sink' for newly synthesized organic material because some microflagellates can

\footnotetext{
- Contribution Nos 3836 from Lamont-Doherty Geological Observatory and 5864 from Woods Hole Oceanographic Institution

- Present address: Department of Biology, Marine Botany, University of Oslo, P.O.B. 1069, N-0316 Oslo 3, Norway
}

prey directly on phytoplankton cells nearly their own size (Goldman \& Caron 1985). Through herbivory, microflagellates reduce the amount of primary productivity available to larger zooplankton by that portion of the phytoplankton biomass which is ingested but not incorporated (i.e. egested as organic material or respired). Since microflagellates and their phytoplankton prey are relatively similar in size they would presumably be available as food to the same species of zooplankton. Therefore, microflagellate herbivory is unlike bacterivory in that it does not constitute a mechanism for the transfer of energy up the food chain. Rather, grazing of phytoplankton by microflagellate populations results in a loss in the amount of primary productivity which is available to higher trophic levels.

While microflagellate herbivory may constitute an energetic loss to higher trophic levels, it may be an important mechanism for the regeneration of nutrients and other inorganic compounds from organic material. In this context, these herbivorous protozoa may be of direct importance in the regeneration of nutrients required for phytoplankton growth since remineralization of ingested phytoplankton does not necessarily 
require bacterial degradation. In support of this hypothesis, it has been demonstrated that the growth rates of bacterivorous microflagellates are relatively high (Davis 1982, Fenchel 1982a, Sherr \& Sherr 1983, Caron 1984) and thus able to keep pace with phytoplankton growth. In addition, microflagellates can withstand periods of starvation and yet remain responsive to the addition of food (Fenchel 1982b). Bacterivorous microflagellates also possess relatively rapid weight-specific respiration rates during exponential growth (Fenchel 1982a, Fenchel \& Finlay 1983), providing the potential for remineralization of a significant fraction of the ingested food. If herbivorous microflagellates possess analogous characteristics, then they may be important in the direct remineralization of some portion of the primary productivity of plankton communities. Despite the potential importance of this role for microflagellates, there have been virtually no attempts to characterize herbivory by these phagotrophic protozoa.

As part of a large-scale study on herbivory in microflagellates, we have demonstrated that the microflagellate Paraphysomonas imperforata, in addition to consuming bacterial prey, is capable of preying on phytoplankton cells nearly as large as itself (Goldman et al. 1985, Goldman \& Caron 1985, Andersen et al. unpubl.). $P$. imperforata was found to be directly responsible for the bulk of the remineralization of particulate organic nitrogen (Goldman et al. 1985) and phosphorus (Andersen et al. unpubl.) when preying on cultures of either the diatom Phaeodactylum tricornutum or bacteria. In this paper we describe carbon cycling in these experiments and some aspects of microflagellate population dynamics. $P$. imperforata was the primary factor controlling the loss of POC from $P$. tricornutum cultures. POC concentration in cultures inoculated with the microflagellate was reduced by approximately $65 \%$ during the $8 \mathrm{~d}$ experiments and only a small fraction of this loss $(10 \%)$ reappeared as DOC. We conclude that herbivorous microflagellates may be important consumers of primary production in plankton communities, resulting in the direct remineralization of a significant fraction of newly synthesized organic material.

\section{METHODS AND MATERIALS}

Three experimental protocols (referred to herein as Experiments A, B and C) were used to investigate carbon cycling between the diatom Phaeodactylum tricornutum, bacteria (a mixed natural bacterial assemblage or a pure culture of Pseudomonas halodurans), and the heterotrophic microflagellate Paraphysomonas imperforata. A detailed description of the experimental design is given in the preceding paper (Goldman et al. 1985). Experiment A was performed at $24^{\circ} \mathrm{C}$ and involved all possible combinations of the alga, bacteria (natural assemblage passing a $0.8 \mu \mathrm{m}$ Nuclepore filter) and microflagellate. The N : P ratio of the growth media was 10:1 (nitrogen limiting) but the grazing phase of the experiment was started while the cultures of $P$. tricornutum or bacteria were still in the exponential phases of growth. Experiment B contained the same combinations of algae, bacteria (in this case a pure culture of $P$. halodurans) and microflagellate except that the bacteria/microflagellate combination was omitted. This experiment was performed at $20^{\circ} \mathrm{C}$ with growth media which had an N:P ratio of $50: 1$ to $60: 1$ (phosphorus limiting). The grazing phase of this experiment was also started during the exponential phase of algal growth. Experiment $C$ (performed at $20^{\circ} \mathrm{C}$ ) consisted of 2 cultures of $P$. tricornutum grown to stationary phase under conditions of nitrogen or phosphorus limitation, and 1 culture of $P$. halodurans grown to stationary phase under conditions of phosphorus limitation. These cultures were then inoculated with the microflagellate. Two additional axenic cultures of P. tricornutum in Experiment C (1 nitrogen limited and 1 phosphorus limited) were also grown to stationary phase but were not inoculated with the microflagellate.

All cultures were placed in continuous darkness at the beginning of the grazing phase of the experiments and stirred by means of a magnetic mixer. Changes in the density of all microbial populations and their cell volumes were periodically monitored in the cultures. Cell numbers were determined for all trials by microscopical counts as described by Goldman et al. (1985). Cell volumes were estimated from microscopical measurements and also using a Coulter Counter with a $70 \mu \mathrm{m}$ aperture. The latter technique gave consistently higher volume measurements than microscopical observations, possibly due to aggregation in some of the trials, and the microscopically determined volumes were used for the calculation of cell yield and weight specific respiration rates.

POC was measured in all cultures with a Perkin Elmer 240 elemental analyzer on $25 \mathrm{mI}$ samples retained on pre-combusted Whatman GF/F glass fiber filters. Filtrates from the POC samples were used to measure the concentration of DOC using the procedure of Menzel \& Vaccaro (1964) as modified by Sharp (1973). Results of the DOC analysis from Experiments $B$ and $C$ were not used in the data analysis because of probable contamination during sampling. The tip of the gravity-fed siphon used to draw samples from the carboys in these experiments (see Goldman et al. 1985) was placed in alcohol between samplings to prevent microbial contamination. Incom- 
plete flushing of the siphon tube prior to each sampling yielded inconsistently variable DOC concentrations, presumably a result of alcohol contamination.

The respiration rates in each culture vessel were measured during Experiments B and C with a Strathkelvin radiometer type oxygen electrode. Samples were placed in glass syringes wrapped in black tape to exclude light and incubated at the same temperature as the experimental trial. Oxygen concentration in the syringe was determined initially and twice during the incubations between 0.5 and $6 \mathrm{~h}$ after the initial measurement. The reduction in oxygen concentration was used to calculate the rate of oxygen consumption in the cultures ( $\mathrm{nl} \mathrm{O} \mathrm{O}_{2}$ consumed $\mathrm{l}^{-1} \mathrm{~h}^{-1}$ ).

The respiration rate of Paraphysomonas imperforata was calculated by comparing respiration in cultures with and without the microflagellate. Respiration rates in axenic cultures of Phaeodactylum tricornutum were used to determine the respiration rate of the diatom (nl $\mathrm{O}_{2}$ cell $^{-1} \mathrm{~h}^{-1}$ ) over the course of the experiment and a linear regression of the decrease in respiration rate with time was constructed. The contribution of $P$. tricornutum respiration to the total respiration in experimental trials inoculated with $P$. imperforata was then calculated for each sample based on this regression, the time (relative to the initiation of the trial), and the density of $P$. tricornutum in the sample. The respiration rate of $P$. imperforata was then calculated by subtracting the $P$. tricornutum respiration from the total respiration and dividing by the density of microflagellates in the sample.

Bacterial respiration in Phaeodactylum tricornutum cultures inoculated with bacteria and microflagellates was not distinguishable from respiration in $P$. tricornutum cultures inoculated with only microflagellates. Therefore, the contribution of bacterial respiration to total respiration in these cultures was not determined. The decrease of the bacterial respiration in the bacterial culture in Experiment $\mathrm{C}$ was calculated in a manner similar to that used to calculate $P$. tricornutum respiration. However, in determining the bacterial regression we did not take into account the possibility of an increase in bacterial respiration during the experiment due to growth of the bacteria on the excretory products of the microflagellates (see Fig. $4 \mathrm{~B}$ in Goldman et al. 1985).

Cell yield (the conversion of prey biomass into Paraphysomonas imperforata biomass) was estimated in 2 ways at that sampling period during late exponential growth of the microflagellate where the first significant decrease in prey density occurred. First, the biovolume of the ingested prey was determined by multiplying the prey cell volume (based on microscopical measurements) by the number of prey consumed. The biovolume of the microflagellate was determined by multiplying the cell volume of the microflagellate by its density at the later of the 2 sampling periods. Yield was then calculated by dividing the prey biovolume consumed by the microflagellate biovolume produced.

The second technique for estimating cell yield was based on the change in the POC concentration over the sampling period. The POC attributable to the prey remaining in the sample was calculated by multiplying the prey density by the POC cell-1 (determined at the initial sampling). This value was subtracted from the initial POC concentration and the POC concentration in the sample to correct for unconsumed prey. The corrected POC concentration during late exponential growth was then divided by the corrected initial POC concentration to obtain the net yield. We may have overestimated net yield with this procedure because we assumed that all POC other than unconsumed prey was microflagellate $\mathrm{POC}$. We also did not take into account the decrease in POC cell-1 of the prey between the initial sampling period and the sample used to calculate yield.

Ingestion rates and clearance rates were determined for the microflagellate based on changes in cell number and were calculated using the equations of Frost (1972) as modified by Heinbokel (1978). Ingestion rates (prey consumed flagellate ${ }^{-1} \mathrm{~d}^{-1}$ ) of the microflagellate were determined at the sampling period which first showed a significant decrease in prey density. Ingestion rates calculated at this sampling time were the highest observed during the trial and were assumed to be the maximum rate for the microflagellate under the imposed culture conditions and food type. Clearance rates for the microflagellate were calculated for each 2 consecutive samples throughout late exponential and early stationary growth until the prey density no longer continued to decrease. The maximum clearance rate for an experimental trial was assumed to be the highest rate observed during this period (usually observed in the early stationary growth phase).

\section{RESULTS}

\section{Particulate and dissolved organic carbon}

Changes in the concentration of POC in the Phaeodactylum tricornutum cultures were greatly affected by the presence or absence of Paraphysomonas imperforata, but relatively unaffected by the presence or absence of bacteria (Fig. 1). In the control culture of $P$. tricornutum alone, we found a $15 \%$ loss in POC over the course of Experiment A (Fig. 1A). A concomitant increase in the concentration of DOC in this culture vessel accounted for virtually all of the 


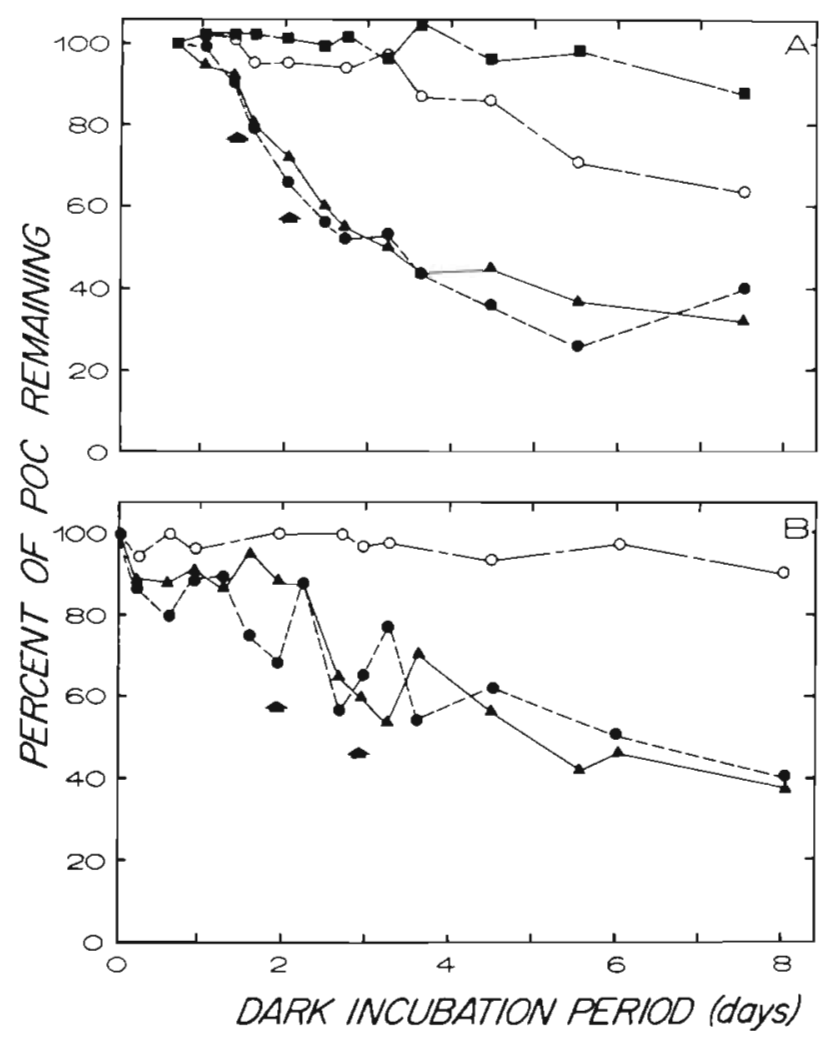

Fig. 1. Phaeodactylum tricomutum. Percent of particulate organic carbon remaining in cultures. Trials performed at (A) $24^{\circ} \mathrm{C}$ and (B) $20^{\circ} \mathrm{C}$. Cultures contained (a) P. tricornutum only; (A) $P$. tricornutum inoculated with Paraphysomonas imperforata; (O) $P$. tricornutum inoculated with bacteria $(\bullet)$. tricornutum inoculated with $P$. imperforata and bacteria. Arrows: the first sample to show a significant decrease in density of $P$. tricornutum, and the end of exponential growth of $P$. imperforata, respectively

POC loss (Fig. 2A). We conclude that the amount of POC removed by $P$. tricornutum respiration after $0.5 \mathrm{~d}$ of incubation in the dark was negligible compared to the total POC concentration. This conclusion is sup- ported by our measurements of respiration rate which showed that total respiration in the $P$. tricornutum cultures decreased dramatically during the first day in darkness (see below).

In the Phaeodactylum tricornutum culture inoculated with bacteria in Experiment $\mathrm{A}$, we found a decrease of $36 \%$ of the POC over the course of the experiment, a loss of $21 \%$ more POC than in the absence of bacteria. The concentration of DOC in this culture vessel did not increase (Fig. 2B). Therefore, bacteria may have accounted for a loss of organic carbon totalling $36 \%$ of the initial POC concentration (P. tricornutum respiration was negligible). Since $40 \%$ of the organic carbon removed by bacteria was DOC released by $P$. tricornutum (compare Fig. 2A with 2B), a loss of $21 \%$ of the initial POC may have been due to bacterial decomposition of POC in living diatoms. However, we believe that aggregation of bacteria and diatoms and their attachment to the walls of the culture vessel, rather than the decomposition of living diatoms, may explain most of the additional loss of POC which was observed in this culture vessel. Wall growth in the presence of the mixed bacterial assemblage in the P. tricornutum cultures of Experiment A may have reduced the POC concentration observed in the siphon-collected samples, resulting in an overestimation of the potential importance of bacteria in POC loss. This hypothesis is supported by the observation that living phytoplankton are not readily susceptible to bacterial attack (Droop \& Elson 1966), and by the fact that the loss of POC in the P. tricornutum culture inoculated with a pure culture of Pseudomonas halodurans was only $9 \%$ of the POC initially present in this culture (Fig. 1B). Aggregation and wall growth were much more apparent in Experiment $A$ compared to Experiment $B$, and were presumably due to bacterial processes carried out by the mixed bacterial assemblage but not by $P$. halodurans (Biddanda 1985).

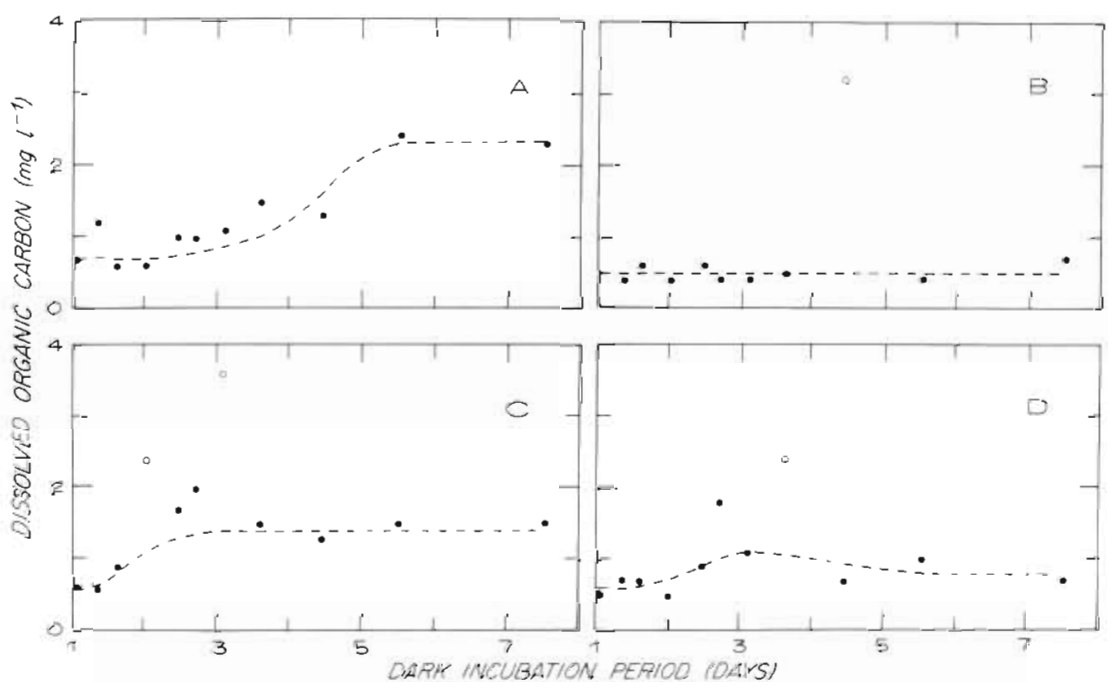

Fig. 2. Dissolved organic carbon concentration in cultures grown at $24^{\circ} \mathrm{C}$ (Experiment A). Cultures contained (A) Phaeodactylum tricornutum only. (B) $P$. tricornutum inoculated with bacteria, (C) Paraphysomonas imperforata, (D) bacteria and P. imperforata. Open symbols: suspected of contamination. Dashed lines: general trends 
In contrast to these results, when Phaeodactylum tricornutum cultures were inoculated with Paraphysomonas imperforata, $68 \%$ (Experiment A) or $61 \%$ (Experiment $B$ ) of the POC was removed by the conclusion of the experiments (Fig. 1) and only a small fraction $(\sim 10 \%)$ of the POC reappeared as DOC (Fig. 2C). Two additional trials with $P$. tricornutum and $P$. imperforata in Experiment $C$ yielded similar results (61 and $75 \%$ of the POC removed). Wall growth was not observed in these cultures and therefore the samples were representative of the cultures.

DOC concentration in the culture vessel containing Phaeodactylum tricornutum and Paraphysomonas imperforata in Experiment A began to increase approximately $1.5 \mathrm{~d}$ after inoculation with $P$. imperforata and approximately $2 \mathrm{~d}$ earlier than in the vessel with only $P$. tricornutum. This increase corresponded to the late exponential growth phase of the flagellate (see Fig. 3A in Goldman et al. 1985) and presumably was related to flagellate feeding activity. The increase in DOC due to growth of the flagellate was less than the total DOC released in the culture vessel containing only $P$. tricornutum (approximately $1 / 2$ ). No increase in DOC was observed once the flagellate entered stationary growth, indicating that the loss of organic carbon during this growth stage must have been due to respiration and not the release of DOC as was the case with $P$. tricornutum. Changes in the concentration of DOC in Experiment $\mathrm{B}$ were similar to those in Experiment $\mathrm{A}$ but were confounded by contamination during the sampling process (see 'Methods and Materials').

Loss of POC in the presence of Phaeodactylum tricornutum, Paraphysomonas imperforata and bacteria was indistinguishable from loss of POC with $P$. tricornutum and $P$. imperforata alone. The concentration of DOC in the culture vessel containing all 3 microbial populations appeared to increase slightly 1.5 to $3 \mathrm{~d}$ after inoculation with flagellates and bacteria (Fig. 2D). However, DOC concentration subsequently decreased to its initial concentration (presumably due to bacterial uptake).

\section{Respiration}

Measurements of respiration in Experiment B confirmed the importance of Paraphysomonas imperforata and the small contribution of bacteria to carbon flow in the Phaeodactylum tricornutum cultures (Fig. 3). The total amount of oxygen consumed was similar for $P$. tricornutum cultures with or without bacteria, and for $P$. tricornutum cultures inoculated with $P$. imperforata and also with or without bacteria. The axenic cultures of $P$. tricornutum were not monitored long enough to observe a significant effect of bacterial respiration of DOC on the total system respiration in the diatom

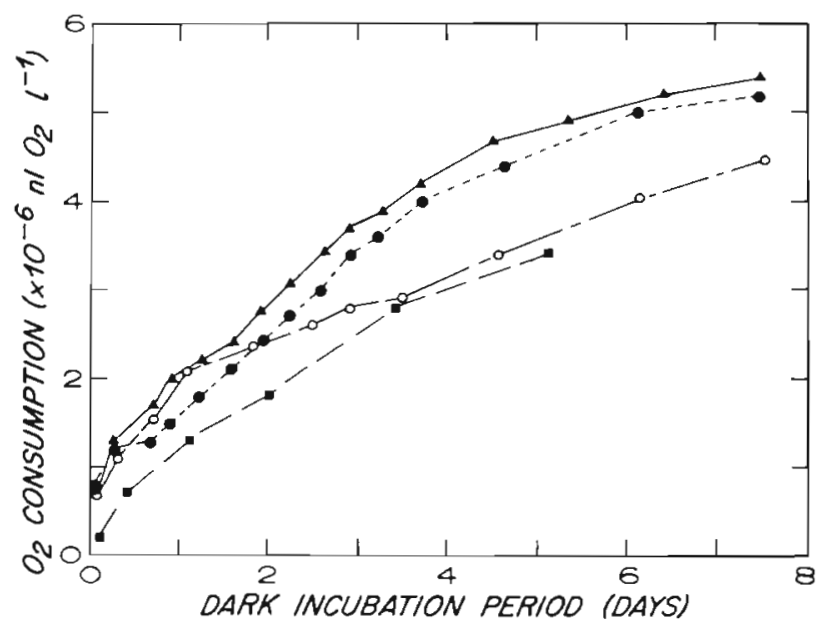

Fig. 3. Phaeodactylum tricornutum. Estimated total oxygen consumption in cultures. Oxygen consumption calculated by multiplying respiration rate measured at each sampling period by $1 / 2$ amount of time elapsed between previous and subsequent sampling periods, and summing over duration of experiment. All trials performed at $20^{\circ} \mathrm{C}$ (Experiments B \& C). Results of 2 axenic cultures in Experiment $C$ were pooled to give this curve. Cultures contained (a) P. tricornutum only, (৯) P. tricornutum inoculated with Paraphysomonas imperforata; (O) bacteria; ( $\bullet$ ) P. imperforata and bacteria

culture containing bacteria. The $\mathrm{pH}$ of all cultures decreased due to respiration during the growth phase of the experiments. The range of the decrease in all cultures was 0.10 to 0.65 . The average decrease in $\mathrm{pH}$ for the cultures inoculated with the microflagellate (with or without bacteria) was 0.44 , twice the magnitude of the decrease for the cultures without flagellates.

Appreciable respiration occurred in axenic cultures of Phaeodactylum tricornutum. Two axenic cultures in Experiment C (1 grown under nitrogen limitation and 1 under phosphorus limitation) showed similar initial respiration rates when placed in continuous darkness $\left(\overline{\mathrm{X}}=1.03 \times 10^{-4} \mathrm{nl} \mathrm{O}_{2}\right.$ cell $\left.^{-1} \mathrm{~h}^{-1}\right)$ and similar patterns of decreasing respiration rate during the dark incubation. The respiration rate of $P$. tricornutum in these cultures in the dark decreased exponentially according to the equation:

$$
\begin{gathered}
\log \text { of respiration rate }= \\
(-0.176) \text { (time in darkness) }+(-3.99)
\end{gathered}
$$

The averaged total oxygen consumption for these cultures during the dark incubation is given in Fig. 3. Total oxygen consumption in the cultures of $P$. tricornutum without microflagellates averaged approximately two-thirds of the total oxygen consumption in cultures with microflagellates.

Respiration rates of Phaeodactylum tricornutum at the beginning of the dark incubation were much lower in the axenic cultures of Experiment $C$ than in all other 
cultures of Experiments B and C, and may have been due to the highly nutrient-stressed condition of the diatoms in the axenic cultures. On reaching stationary phase, these cultures were kept in the light $24 \mathrm{~h}$ longer than the other cultures of Experiment $C$, and, therefore, were presumably in a later stage of stationary growth. $P$. tricornutum respiration rates in the axenic cultures decreased by a factor of 2.2 (range $=1.6$ to 2.9 ) during the first day in the dark incubation, while in the other cultures the rates decrease by a factor of 6.3 (range $=$ 2.2 to 9.1) during the first day, and then continued to decrease exponentially according to the equation:

$$
\begin{gathered}
\log \text { of respiration rate }= \\
(-0.357) \text { (time in darkness) }+(-3.69)
\end{gathered}
$$

As a result, most of the respiration due to $P$. tricornutum in these latter cultures occurred near the beginning of the incubation in continuous darkness. The respiration rate at each sampling period over the course of an experiment showed this clearly (Fig. 4). Total respiration decreased significantly before any significant decrease in the density of $P$. tricornutum. The peak in respiration occurring at Day 2 through Day 4 corresponded to the increase in the density of the microflagellate. The individual contributions of $P$. tricornutum and Paraphysomonas imperforata respiration were calculated for the population changes and total system respiration described in Fig. 4. When summed over the entire course of the experiment, flagellate and $P$. tricornutum respiration accounted for 68 and $32 \%$ of the total system respiration, respectively (although most of the $P$. tricornutum respiration took place in the first $0.5 \mathrm{~d}$ of incubation). If the first $0.5 \mathrm{~d}$ of incubation are excluded, then flagellate and diatom respiration accounted for 82 and $18 \%$ of the total system respiration, respectively.

On the basis of the POC and respiration data given

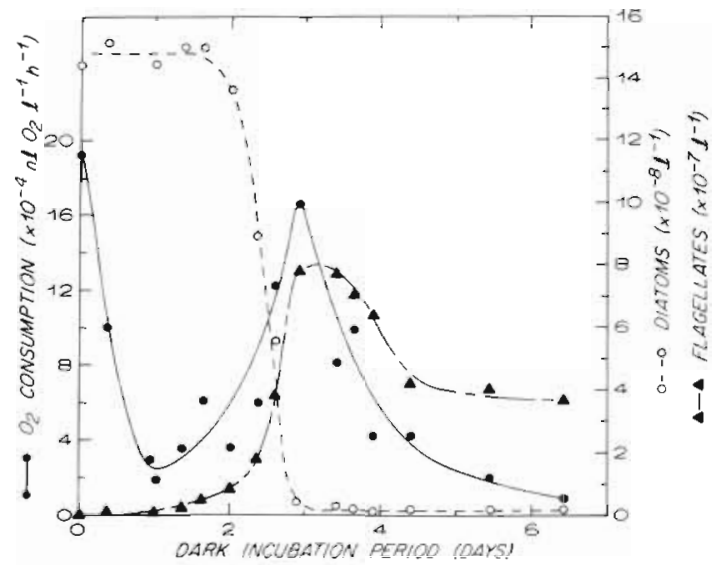

Fig. 4. Phaeodactylum tricornutum. Population changes and concomitant instantaneous rates of oxygen consumption for culture inoculated with Paraphysomonas imperforata in Experiment $\mathrm{C}$ above, a rough carbon budget for this experimental trial can be calculated. In summary, approximately $32 \%$ of the POC present at the beginning of the incubation was still present at the conclusion. This POC included unconsumed Phaeodactylum tricornutum (totalling $\sim 2 \%$ of the initial POC), Paraphysomonas imperforata biomass and egested POC (egested POC, most likely contained in empty diatom frustules, constituted $10 \%$ of the initial $\mathrm{POC}_{i}$ see 'Cell yield' below). A loss of $10 \%$ of the initial POC was also attributable to the increase in the concentration of DOC. Therefore, the remaining $58 \%$ of the organic carbon initially present as POC was respired jointly by $P$. tricornutum and $P$. imperforata. Based on the results of Fig. $4,40 \%$ of the initial POC was respired by $P$ : imperforata and $18 \%$ by P. tricornutum.

Both the respiration rate of Paraphysomonas imperforata (Fig. 5) and the cell volume (Fig. 6) were highly dependent on the growth stage of the microflagellate. The respiration rate decreased exponentially according to the equation:

$$
\begin{gathered}
\log \text { of respiration rate }= \\
(-0.193) \text { (time) }+(-2.67)
\end{gathered}
$$

where 'time' $=$ length of time since the initiation of stationary growth. The results of the culture containing

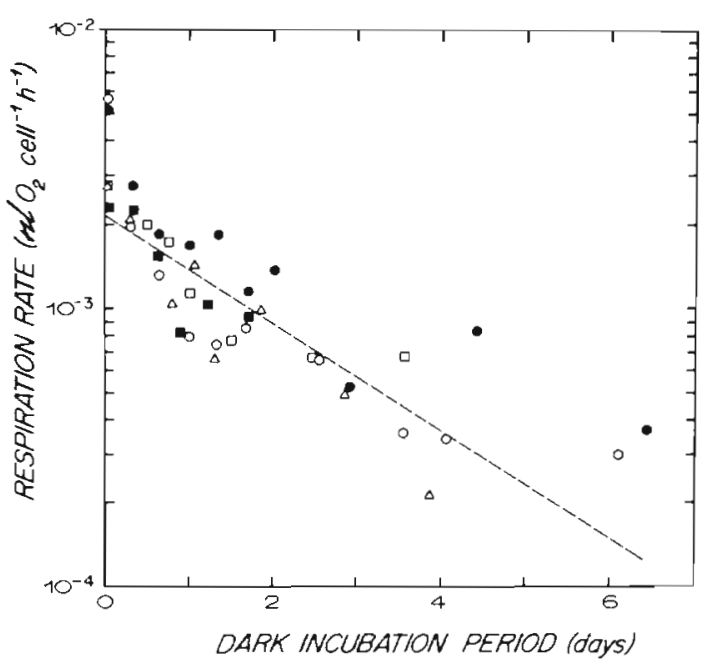

Fig. 5. Paraphysomonas imperforata. Respiration rate of culture fed Phaeodactylum tricornutum or bacteria in 5 trials at $20^{\circ} \mathrm{C}$ (Experiments B \& C). Respiration rates during late exponential growth of the flagellate were used as initial sample. Regression excludes culture containing the diatom, flagellate and bacteria because of probable influence of bacterial respiration on calculation of flagellate respiration rate. (-) $P$. imperforata fed phosphorus-limited bacteria (Experiment C); ( $\square$ ) $P$. imperforata fed phosphorus-limited $P$. tricomutum (Experiment $C$ ): $(\triangle) P$. imperforata fed nitrogenlimited $P$. tricomutum (Experiment $C$ ); (O) P. imperforata fed non nutrient-limited $P$. tricornutum (Experiment $\mathrm{B}$ ); $(\bullet) P$. imperforata fed non nutrient-limited $P$. tricornutum, and with bacteria (Experiment C) 


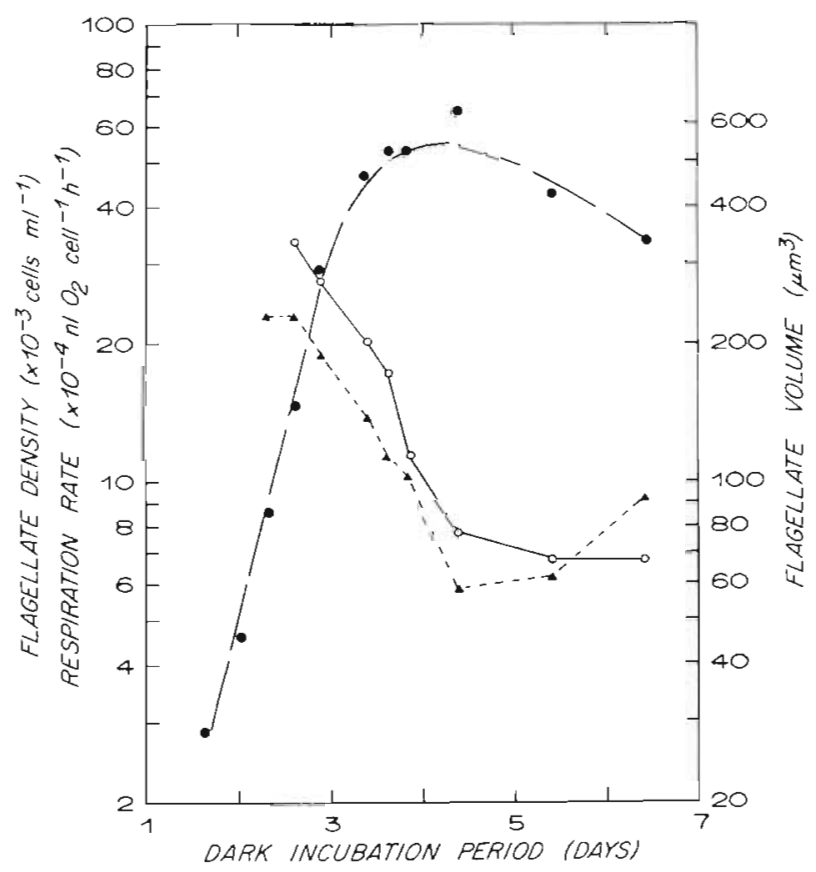

Fig. 6. Paraphysomonas imperforata. Relation between growth stage, cell volume and respiration rate of culture fed Phaeodactylum tricornutum. P. tricornutum grown at $20^{\circ} \mathrm{C}$ under phosphorus limitation (Experiment C). (•) microflagellate density; ( $)$ cell volume; (O) respiration rate

Phaeodactylum tricornutum with bacteria were not used to calculate the regression in Fig. 5 because of the evidence for cryptic growth of the bacteria. The decrease in the respiration rate of the flagellate was calculated separately for this culture. If we assume that the difference between this regression and the regression based on the other cultures was due to bacterial respiration, then we can calculate that the bacterial respiration rate at $6.44 \mathrm{~d}$ was $1.07 \times 10^{-6} \mathrm{nl} \mathrm{O}_{2}$ cell ${ }^{-1} \mathrm{~h}^{-1}$. This value is approximately $6 \times$ greater than the bacterial respiration calculated from the rate of decrease of respiration when only bacteria were present in a culture (i.e. where there was no release of organic material by flagellate grazing). This calculation indicates that respiration due to the cryptic growth of bacteria can contribute significantly to oxygen consumption in cultures of microflagellates in stationary growth, and, if unaccounted for, may provide erroneously high estimates of microflagellate respiration rate.

Microflagellate cell volume decreased at the onset of stationary phase (starvation conditions) and continued for $2 \mathrm{~d}$ following exhaustion of the food supply (Fig. 6). Microscopical observation confirmed that the microflagellates continued to remain viable during this period despite a 4 -fold decrease in cell volume $(\sim 240$ to $\sim 60 \mu^{3}$ ). Decreases in the respiration rate of Paraphysomonas imperforata were commensurate with

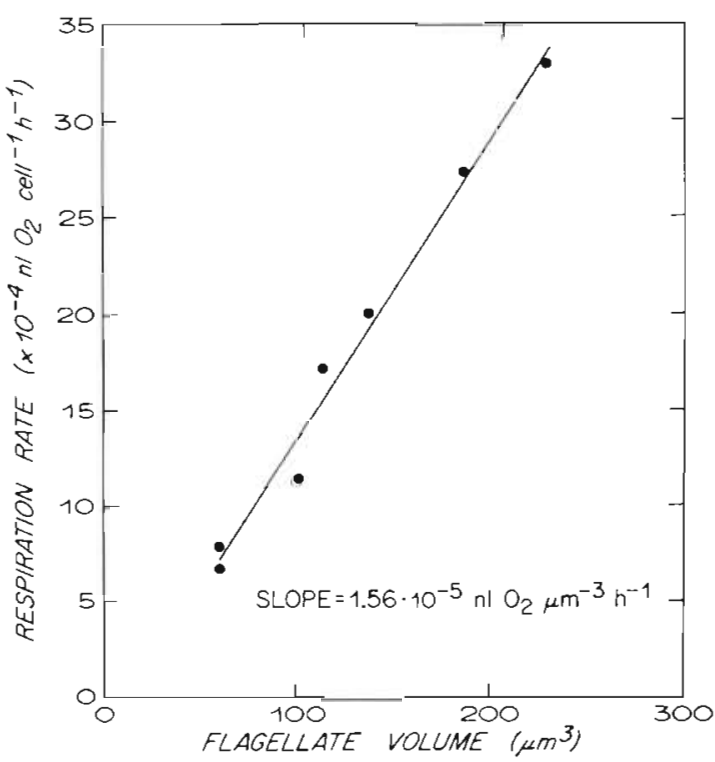

Fig. 7. Paraphysomonas imperforata. Respiration rate as a function of flagellate volume. Phaeodactylum tricornutum prey grown at $20^{\circ} \mathrm{C}$ under phosphorus limitation (Experiment C)

decreases in cell volume during stationary phase and showed a fairly tight correlation within a single experimental trial (Fig. 7). Respiration rates ( $\mathrm{nl} \mathrm{O} \mathrm{O}_{2}$ cell $^{-1} \mathrm{~h}^{-1}$ ) at the termination of the experiments ranged from 5.4 to $24.4 \%(\overline{\mathrm{X}}==11.2 \%)$ of the rates observed during late exponential growth for 4 trials.

'Maximal' respiration rates of Paraphysomonas imperforata (rates measured during late exponential growth) varied from $2.33 \times 10^{-3}$ to $5.61 \times 10^{-3} \mathrm{nl} \mathrm{O}$ cell ${ }^{-1} \mathrm{~h}^{-1}$ for experiments at $20^{\circ} \mathrm{C}$ (Table 1 ). The differences in these rates are explainable as differences in $P$. imperforata growth rate as well as cell volume. The highest respiration rates $\left(5.14 \times 10^{-3}\right.$ and $5.61 \times 10^{-3} \mathrm{nl} \mathrm{O}_{2}$ cell $^{-1} \mathrm{~h}^{-1}$ ) were observed for $P$. imperforata which grew on non nutrient-limited Phaeodactylum tricornutum at $\mu=2.5 \mathrm{~d}^{-1}$. Microflagellates which grew on nutrient-limited $P$. tricornutum at $\mu=2.1$ to $2.3 \mathrm{~d}^{-1}$ had lower respiration rates $\left(2.73 \times 10^{-3}\right.$ to $2.76 \times 10^{-3} \mathrm{nl} \mathrm{O}{ }_{2}$ cell $\left.^{-1} \mathrm{~h}^{-1}\right)$ despite the larger cell volumes of these flagellates. The lowest respiration rate was observed for $P$. imperforata which grew on bacteria at a growth rate comparable to growth on non-nutrient-limited $P$. tricornutum $\left(\mu=2.5 \mathrm{~d}^{-1}\right)$. However, the average cell volume of $P$. imperforata was significantly less $(1 / 3$ to $2 / 3)$ when it was fed bacteria than when it was fed $P$. tricornutum. Thus, when the respiration rates of the microflagellates are normalized to flagellate volume, the rate observed for flagellates fed bacteria and growing at $\mu=2.5 \mathrm{~d}^{-1}$ is comparable to the rates for flagellates fed $P$. tricornutum and growing at $\mu=2.5 \mathrm{~d}^{-1}$. 
Table 1. Paraphysomonas imperforata. Growth rates and maximum respiration rates when fed Phaeodactylum tricornutum and Pseudomonas halodurans

\begin{tabular}{|c|c|c|c|}
\hline \multicolumn{2}{|l|}{ Prey } & \multicolumn{2}{|c|}{ Paraphysomonas imperforata } \\
\hline Food type and growth conditions & $\begin{array}{l}\text { Initial density } \\
\quad\left(\text { No. } \mathrm{ml}^{-1}\right)\end{array}$ & $\begin{array}{l}\text { Growth rate } \\
\qquad\left(\mathrm{d}^{-1}\right)\end{array}$ & $\begin{array}{l}\text { Maximum } \\
\text { respiration rate } \\
\left(\mathrm{nl} \mathrm{O}_{2} \text { cell }^{-1} \mathrm{~h}^{-1}\right)\end{array}$ \\
\hline Pseudomonas halodurans: phosphorus-limited, Experiment C & $2.00 \times 10^{7}$ & 2.47 & $2.31 \times 10^{-3}$ \\
\hline Phaeodactylum tricornutum: non-limited, Experiment B & $4.55 \times 10^{5}$ & 2.55 & $5.61 \times 10^{-3}$ \\
\hline $\begin{array}{l}\text { Phaeodactylum tricornutum with Pseudomonas halodurans: } \\
\text { non-limited, Experiment B }\end{array}$ & $4.55 \times 10^{5}$ & 2.52 & $5.14 \times 10^{-3}$ \\
\hline Phaeodactylum tricornutum: phosphorus-limited, Experiment C & $1.01 \times 10^{6}$ & 2.10 & $2.76 \times 10^{-3}$ \\
\hline Phaeodactylum tricornutum: nitrogen-limited, Experiment $\mathrm{C}$ & $1.46 \times 10^{6}$ & 2.31 & $2.73 \times 10^{-3}$ \\
\hline
\end{tabular}

Table 2. Paraphysomonas imperforata. Yield (volume: volume) when fed bacteria, Phaeodactylum tricornutum, or both ( \pm 1 SD for overail average)

\begin{tabular}{|lccc|}
\hline \multicolumn{1}{|c}{ Prey } & $\begin{array}{c}\text { Number } \\
\text { of trials }\end{array}$ & \multicolumn{2}{c|}{ Yield (\%) } \\
& 2 & 39 to 49 & 44 \\
\hline $\begin{array}{l}\text { Bacteria } \\
\text { Phaeodactylum } \\
\text { tricornutum }\end{array}$ & 4 & 35 to 62 & 43 \\
$\begin{array}{l}\text { Bacteria and Phaeo- } \\
\text { dactylum tricornutum } \\
\text { Overall }\end{array}$ & 2 & 31 to 58 & 44 \\
\hline
\end{tabular}

\section{Cell yield}

The average yield of microflagellate biomass determined at late exponential growth was $44 \%$ based on cell volume (Table 2) and was similar for flagellates fed bacteria, Phaeodactylum tricornutum, or both. The variance associated with the overall average $(11 \%)$ is most likely attributable to differences in food quality $(2$ types of bacterial prey were used and $P$. tricornutum was grown under 3 nutrient regimes), the error associated with the population counts, differences in the exact stage of growth at which yield was determined in the 8 trials, or combinations of these potential factors. However, the temperature difference $\left(4 \mathrm{C}^{\circ}\right)$ between Experiments $\mathrm{A}$ and $\mathrm{B} / \mathrm{C}$ presumably did not influence yield since in subsequent work we have found that yield of the microflagellate when fed $P$. tricornutum is not highly temperature dependent (Caron et al. unpubl.). The yields given in Table 2 were determined on samples taken prior to the beginning of the stationary growth phase of the microflagellates. We also calculated yield by comparing the total amount of microflagellate biomass produced per unit of diatom or bacterial biomass initially present in the cultures. The results of this method also showed no discernable difference in the yield due to prey type or nutrient status of the prey.

Yield calculated on the basis of POC remaining in the culture vessels (see 'Methods and Materials') averaged $58 \%$, which is $14 \%$ higher than yield calculated on the basis of volume. For 55 samples taken during late exponential to late stationary growth phase in 8 trials, yield based on POC averaged $10 \%$ higher than yield based on volume. This systematic discrepancy was presumably a result of prey ingested but not incorporated by flagellates (egested POC). Therefore, $10 \%$ of the ingested POC was apparently egested as unincorporated POC. This egested POC may have been contained in the organic matrix of the empty diatom frustules.

\section{Ingestion and clearance rates}

Observed ingestion rates were correlated with prey density in a classical saturation pattern (Fig. 8). There was, however, a large variability in this relationship which may have been due to chemical composition of the prey. 'Maximum' ingestion rates $\left(\mathrm{I}_{\mathrm{m}}\right)$ of the microflagellates in 6 trials averaged 71 Phaeodactylum tricornutum flagellate ${ }^{-1} \mathrm{~d}^{-1}$ (range of 40 to $111 P$. tricornutum flagellate ${ }^{-1} \mathrm{~d}^{-1}$ ). Assuming that the initial POC concentration in the trials was composed primarily of prey biomass, this ingestion rate corresponds to $518 \mathrm{pgC}$ flagellate ${ }^{-1} \mathrm{~d}^{-1}$ (range of 292 to $810 \mathrm{pgC}$ flagellate $\mathrm{d}^{-1}$ ) for Paraphysomonas imperforata fed $P$. tricornutum. Maximum ingestion rates determined for the 2 trials containing only bacteria were 560 and 2,820 bacteria flagellate ${ }^{-1} \mathrm{~d}^{-1}$, which corresponds to 184 and $330 \mathrm{pgC} \mathrm{cell-1} \mathrm{d}^{-1}$. Therefore, although ingestion rates based on the number of cells consumed 


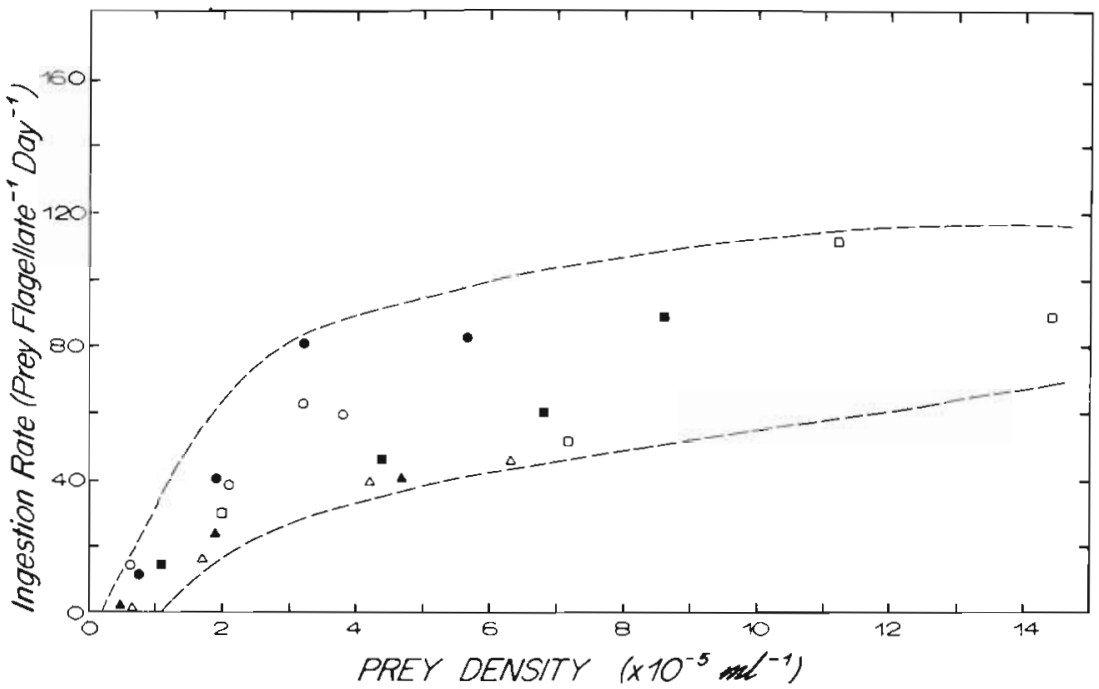

Fig. 8. Paraphysomonas imperforata. Ingestion rates of culture fed Phaeodactylum tricornutum as a function of $P$. tricornutum density in 6 trials. (O) non nutrient-limited $P$. tricornutum at $20^{\circ} \mathrm{C}$ (Experiment $\mathrm{B}$ ); $(\square)$ non nutrient-limited $P$. tricornutum at $20^{\circ} \mathrm{C}$ with bacteria present (Experiment B); (匹) nitrogen-limited P. tricornutum at $20^{\circ} \mathrm{C}$ (Experiment $\mathrm{C}$ ); $(\bullet)$ phosphorus-limited $P$. tricornutum at $20^{\circ} \mathrm{C}$ (Experiment $\mathrm{C}$ ); $(\Delta)$ non nutrientlimited $P$. tricornutum at $24^{\circ} \mathrm{C}$ with bacteria present (Experiment A); ( $\mathbf{\Delta}$ ) non nutrient-limited $P$. tricomutum at $24^{\circ} \mathrm{C}$ (Experiment A) per unit time was much higher for $P$. imperforata fed bacteria, rates based on organic carbon ingested per unit time were generally greater in this study for flagellates fed $P$. tricornutum.

Maximum clearance rates for Paraphysomonas imperforata fed Phaeodactylum tricornutum ranged from $0.95 \times 10^{-4}$ to $2.49 \times 10^{-4} \mathrm{ml}$ flagellate ${ }^{-1} \mathrm{~d}^{-1}$ for 6 trials $\left(\overline{\mathrm{X}}=1.64 \times 10^{-4} \mathrm{ml}\right.$ flagellate $\left.{ }^{-1} \mathrm{~d}^{-1}\right)$, and averaged slightly higher than rates for microflagellates fed bacteria (range $=1.06 \times 10^{-4}$ to $0.56 \times 10^{-4} ; \bar{X}=$ $0.81 \times 10^{-4} \mathrm{ml}$ flagellate $\left.{ }^{-1} \mathrm{~d}^{-1}\right)$. In addition, relatively high threshold concentrations of prey were observed in this study below which $P$. imperforata grazing was ineffective. These thresholds were approximately $10^{4} \mathrm{P}$. tricornutum $\mathrm{ml}^{-1}$ and 1 to $4 \times 10^{6}$ bacteria $\mathrm{ml}^{-1}$. We conclude that the flagellate is only capable of sustained growth in relatively eutrophic waters or in microenvironments of elevated prey density in oligotrophic waters (e.g. marine snow; Caron et al. 1982).

\section{DISCUSSION}

Much of the previous work on the importance of protozoa in the remineralization of organic matter has centered around their role as bacterial consumers. From these studies a general conclusion has emerged that, although Protozoa are instrumental in the degradation of POC, their primary function is to maintain the bacterial assemblage in a stage of 'physiological youth' while most of the remineralization is actually carried out by the bacteria (Javornicky \& Prokesova 1963, Fenchel \& Harrison 1976, Sherr et al. 1982). This conclusion may be valid for the remineralization of non-living organic material such as dead phytoplankton (Sherr et al. 1982) or dissolved organic material released from living phytoplankton (Laacke et al. 1983, Linley et al. 1983). However, from the results of the present study, we conclude that the consumption of photosynthetic eukaryotes by heterotrophic microflagellates of nearly the same size may be an alternative pathway for protozoan-mediated remineralization of POC which largely circumvents the bacterial loop. We have shown that bacteria were relatively ineffective in the remineralization of nitrogen and phosphorus from Phaeodactylum tricornutum or bacteria (Goldman et al. 1985, Andersen et al. unpubl.). The loss of POC from $P$. tricornutum or bacterial cultures in the present study was also largely mediated by Paraphysomonas imperforata. POC of $P$. tricornutum was relatively unaffected in the presence of bacteria alone but decreased markedly in the presence of $P$. imperforata with or without bacteria included. In addition, the loss of diatom POC as DOC was reduced in the presence of $P$. imperforata because the diatoms were consumed before a significant amount of DOC was released (Fig. 2A, C) further reducing the role of bacteria as remineralizers. In contrast to $\mathrm{POC}$, the removal of DOC was largely mediated by bacterial activity (Fig. 2B). Based on the work of Haas \& Webb (1979), it is unlikely that $P$. imperforata utilized DOC.

The growth rate of Paraphysomonas imperforata (Table 1; Goldman et al. 1985) was comparable in Experiments A and B when the microflagellate was grown on Phaeodactylum tricornutum or bacteria. This is contrary to the results of several studies which have noted differences in the growth of bacterivorous and herbivorous protozoa fed different prey species (Rubin \& Lee 1976, Taylor \& Berger 1976, Curds \& Bazin 1977. Stoecker et al. 1981, Caron 1984). Cell yields were also similar for $P$. imperforata fed bacteria or $P$. tricornutum and are commensurate with the range of cell yields observed for other microflagellates (Kopylov \& 
Table 3. Comparison of maximum clearance rates of Paraphysomonas imperforata observed in this study with clearance rates measured for other microflagellates

\begin{tabular}{|c|c|c|c|}
\hline \multirow[t]{2}{*}{ Species } & \multicolumn{2}{|c|}{ Maximum clearance rate } & \multirow[t]{2}{*}{ Source } \\
\hline & ( $\mathrm{ml}$ flagellate $\mathrm{e}^{-1} \mathrm{~h}^{-1}$ ) & (flagellate cell volume $\mathrm{h}^{-1}$ ) & \\
\hline Monosiga sp. & $2.0 \times 10^{-6}$ & $9.8 \times 10^{4}$ & \multirow{6}{*}{ Fenchel (1982b) } \\
\hline Paraphysomonas vestita & $1.7 \times 10^{-6}$ & $9.1 \times 10^{4}$ & \\
\hline Actinomonas mirabilis & $7.9 \times 10^{-5}$ & $1.1 \times 10^{6}$ & \\
\hline Ochromonas sp. & $1.0 \times 10^{-5}$ & $5.2 \times 10^{4}$ & \\
\hline Pleuromonas jaculans & $1.4 \times 10^{-6}$ & $5.5 \times 10^{4}$ & \\
\hline Pseudobodo tremulans & $1.0 \times 10^{-5}$ & $1.1 \times 10^{5}$ & \\
\hline Actinomonas mirabilis & $2.0 \times 10^{-4}$ & $2.7 \times 10^{6}$ & \multirow{6}{*}{ Davis (1982) } \\
\hline Paraphysomonas imperforata & $1.4 \times 10^{-4}$ & $1.3 \times 10^{6}$ & \\
\hline Bodo celer & $3.9 \times 10^{-5}$ & $2.0 \times 10^{6}$ & \\
\hline Bodo designis & $5.7 \times 10^{-5}$ & $2.8 \times 10^{6}$ & \\
\hline Pseudobodo tremulans & $1.6 \times 10^{-4}$ & $1.8 \times 10^{6}$ & \\
\hline Rhynchomonas nasuta & $3.7 \times 10^{-5}$ & $1.3 \times 10^{6}$ & \\
\hline Monas sp. & $9.5 \times 10^{-7}$ & $3.2 \times 10^{4}$ & Sherr et al. (1983) \\
\hline $\begin{array}{l}\text { Paraphysomonas imperforata } \\
\text { (fed bacteria) } \\
\text { Paraphysomonas imperforata } \\
\text { (fed Phaeodactylum tricornutum) }\end{array}$ & $\begin{array}{c}3.4 \times 10^{-6} \\
\text { Range }=2.3 \text { to } 4.4 \times 10^{-6} \\
6.8 \times 10^{-6} \\
\text { Range }=4.0 \text { to } 10.4 \times 10^{-6}\end{array}$ & $\begin{array}{c}1.9 \times 10^{4} \\
\text { Range }=1.3 \text { to } 2.5 \times 10^{4} \\
2.5 \times 10^{4} \\
\text { Range }=1.5 \text { to } 3.8 \times 10^{4}\end{array}$ & This study \\
\hline
\end{tabular}

Moiseev 1980, Fenchel 1982a, Sherr et al. 1983). As previously stated, the rate of ingestion of diatom biomass exceeded the rate of ingestion of bacterial biomass. Given the fact that growth rates of diatom-fed and bacteria-fed microflagellates were equal, the greater rate of ingestion of microflagellates grazing $P$. tricornutum balanced the larger cell volume and respiration rate (on a cell ${ }^{-1}$ basis) observed for these microflagellates, and resulted in similar cell yields of $P$. imperforata on either prey type (Table 2).

The maximal ingestion rates of Paraphysomonas imperforata, when measured as prey flagellate ${ }^{-1} \mathrm{~d}^{-1}$, were much greater for bacterial prey than for the diatom prey. However, clearance rates of the microflagellate fed bacterial prey were approximately $1 / 2$ the rates of flagellates fed Phaeodactylum tricornutum. In addition, clearance rates observed in this study for $P$. imperforata fed bacteria were lower than rates observed for microflagellates of similar size in other studies (Table 3 ). The specific maximum clearance rate for $P$. imperforata (flagellate cell volume cleared $\mathrm{h}^{-1}$ ) was less than that observed for any flagellate in those studies. $P$. imperforata in the present study also required a relatively high threshold density of bacteria for effective grazing ( 1 to $4 \times 10^{6} \mathrm{ml}^{-1}$ ). These observations indicate that our clone is apparently adapted for preying on bacteria only in eutrophic environments or microenvironments of elevated bacterial density in oligotrophic environments.

Alternatively, it appears that Paraphysomonas imperforata may be better suited for herbivory than bacterivory. The importance of $P$. imperforata for grazing phytoplankton populations can be estimated from the clearance rates we have measured if the density of $P$. inperforata is known. This is beyond the present state of our knowledge concerning the distribution of heterotrophic microflagellates. However, given a maximum clearance rate of $6.83 \times 10^{-6} \mathrm{ml}$ flagellate ${ }^{-1} \mathrm{~h}^{-1}$, a population of $6.1 \times 10^{3}$ microflagellates $\mathrm{ml}^{-1}$ would be required to completely filter the water once a day. Heterotrophic nanoplankton densities of this magnitude are not uncommon in estuarine systems (Sherr \& Sherr 1983, Sherr et al. 1984, Davis et al. 1985). Therefore, the potential exists that herbivorous microflagellates may be significant grazers of photosynthetic nanoplankton in some plankton communities.

The respiration rates observed for Paraphysomonas imperforata in this study are commensurate with rates observed for other bacterivorous microflagellates (Fenchel 1982b, Fenchel \& Finlay 1983). The average weight specific respiration rate for 5 experimental trials was $2.67 \times 10^{-5} \mathrm{nl} \mathrm{O} \mu_{2} \mathrm{~m}^{-3} \mathrm{~h}^{-1}$ (range $=$ $1.09 \times 10^{-5}$ to $4.04 \times 10^{-5}$ ). A reduction in the respiration rate of the microflagellates during starvation similar to that which we have observed was described by Fenchel (1982b). The reduction in cell volume and respiration rate of microflagellates in that study was due to autophagy and was correlated with a reduction in the volume of mitochondria, nuclei and nucleoli. The breakdown of these structures may explain the continued release of remineralized nitrogen and phos- 
phorus at the onset of the stationary growth phase of the microflagellate (Goldman et al. 1985, Andersen et al. unpubl.). If autophagy results in the breakdown of predominantly proteinaceous structures, then we would expect the conservation of phosphorus (but not nitrogen) relative to carbon in microflagellates during late stationary growth (Andersen et al. unpubl.).

Although we did observe a significant reduction in the respiration rate of Paraphysomonas imperforata during starvation, we did not observe a decrease in the weight-specific respiration rate of the microflagellate as has been observed with Ochromonas sp. (Fenchel \& Finlay 1983). Respiration rate of $P$. imperforata in the present study was tightly correlated with cell volume (Fig. 7)

It is difficult to speculate on the ecological implications of the results of this and our previous studies (Goldman et al. 1985, Andersen et al. unpubl.) since our conclusions are based on a single set of interacting microorganisms, and since very little information is available on the distribution and in situ abundance of microflagellates which prey on photosynthetic nanoplankton. In addition, our grazing experiments were conducted in continuous darkness, and we do not know how a normal light-dark cycle might affect the feeding activity of the microflagellate. Nevertheless, our results are consistent with anecdotal accounts of herbivorous microflagellates in marine mass algal cultures (Raymont \& Adams 1958, Goldman \& Stanley 1974, Laws et al. 1983) and in plankton communities (Haas 1982), and are supported by the recent isolation and culture of ecologically analogous microflagellates in freshwater (Boraas 1983, Gude 1983). The ability of some microflagellates to ingest chroococcoid cyanobacteria has also been recently established (Johnson et al. 1982, Caron 1984, Caron et al. 1985). Collectively, these observations suggest a potentially important, but as yet unconfirmed, role for microflagellate herbivory in plankton communities.

We have demonstrated that pathways of energy and nutrient cycling exist in which all components (photosynthetic eukaryotes, bacterivorous/herbivorous eukaryotes, and bacteria) are less than $20 \mu \mathrm{m}$ in size. Furthermore, we have shown that nutrient and organic carbon remineralization may be mediated directly by phytoplankton-grazing microflagellates, thus obviating the need for bacterial decomposition. Although microflagellates incorporate food into protozoan biomass relatively efficiently $(\sim 44 \%)$ their small size presents the possibility that several trophic steps may take place within the nanoplankton and microzooplankton size classes. Each transfer would lead to the remineralization of a significant fraction of the organic carbon present in the prey with the overall result that a relatively small fraction of energy originally fixed by primary production is actually passed on to higher trophic levels. The existence of microflagellates capable of ingesting bacteria and photosynthetic nanoplankton may explain why field studies have indicated that microorganisms less than $20 \mu \mathrm{m}$ in size are responsible for most of the respiration (Pomeroy \& Johannes 1968, Williams 1981) and nutrient regeneration (Glibert 1982, Paasche \& Kristiansen 1982) in marine plankton communities. In addition, it may explain the correlation between the density of heterotrophic nanoplankton and the density of photosynthetic nanoplankton observed but unexplained by Davis et al. (1985). Microflagellate herbivory provides a mechanism for the direct remineralization of living POC, and thus supports the recent contention of rapid phytoplankton growth rates in the oligotrophic ocean (Goldman 1984).

Acknowledgements. The authors gratefully acknowledge the generosity of Dr. Judith Capuzzo who loaned us the oxygen meter and Dr. Dale Levitt who assisted us in its use. We also thank Bonnie Woodward who performed the CHN analysis. This work was supported by Grant No. OCE-83-8578 from the National Science Foundation.

\section{LITERATURE CITED}

Azam, F., Fenchel, T., Field, J. G., Gray, J. S., Meyer-Reil, L. A., Thingstad, F. (1983). The ecological role of watercolumn microbes in the sea. Mar Ecol. Prog. Ser. 10: $257-263$

Boraas, M. E. (1983). Predator-mediated algal evolution in chemostat culture. EOS Trans. Am. Geophys. Un. 64: 1102 (Abstr.)

Biddanda, B. A. (1985). Microbial synthesis of macroparticulate matter. Mar. Ecol. Prog. Ser. 20: 241-251

Caron, D. A. (1984). The role of heterotrophic microflagellates in plankton communities. Ph. D. thesis, Massachusetts Inst. of Tech. and Woods Hole Oceanogr. Inst., p. 1-268

Caron, D. A., Davis, P. G., Madin, L. P., Sieburth, J. McN. (1982). Heterotrophic bacteria and bacterivorous Protozoa in oceanic macroaggregates. Science 218: 795-797

Caron, D. A., Pick, F. R., Lean, D. R. S. (1985). Chroococcoid cyanobacteria in Lake Ontario: Vertical and seasonal distributions during 1982. J. Phycol. 21: 171-175

Curds, C. R., Bazin, M. J. (1977). Protozoan predation in batch and continuous culture. In: Droop, M. R., Tannasch, H. W (ed.) Advances in aquatic microbiology. Academic Press, London, p. 115-176

Davis, P. G. (1982). Bacterivorous flagellates in marine waters. Ph. D. thesis, Univ. of Rhode Island, Kingston, p. $1-218$

Davis, P. G., Caron, D. A., Johnson, P. W., Sieburth, J. McN (1985). Phototrophic and apochlorotic components of picoplankton and nanoplankton in the North Atlantic: Geographic, vertical, seasonal and diel distributions. Mar Ecol. Prog. Ser. 21: 15-26

Davis, P. G., Sieburth, J. McN. (1984). Estuarine and oceanic microflagellate predation of actively growing bacteria: Estimation by frequency of dividing-divided bacteria. Mar. Ecol. Prog. Ser. 19: 237-246 
Droop, M. R., Elson, K. G. R. (1966). Are pelagic diatoms free from bacteria

Fenchel, T. (1982a), Ecology of heterotrophic microflagellates. II. Bioenergetics and growth. Mar. Ecol. Prog. Ser. 8: 225-231

Fenchel, T. (1982b). Ecology of heterotrophic microflagellates. III. Adaptations to heterogeneous environments. Mar. Ecol. Prog. Ser. 9: 25-33

Fenchel, T. (1982c). Ecology of heterotrophic microflagellates. IV. Quantitative occurrence and importance as bacterial consumers. Mar. Ecol. Prog. Ser. 9: 35-42

Fenchel, T., Finlay, B. J. (1983). Respiration rates in heterotrophic, free-living Protozoa. Microb. Ecol. 9: 99-122

Fenchel, T., Harrison, P. (1976). The significance of bacterial grazing and mineral cycling for the decomposition of particulate detritus. In: Anderson, J, M., Macfadyen, A. (ed.) The role of terrestrial and aquatic organisms in decomposition processes. Blackwell Scientific Publications, Oxford, p. 285 299

Frost, B. (1972). Effects of size and concentration of food particles on the feeding behavior of the marine planktonic copepod Calanus pacificus. Limnol. Oceanogr. 17: 805-815

Glibert, P. (1982). Regional studies of daily, seasonal and size fraction variability in ammonium remineralization. Mar. Biol. 70: 209-222

Goldman, J. C. (1984). Oceanic nutrient cycles. In: Fasham, M. J. (ed.) Flows of energy and materials in marine ecosystems: theory and practice. Plenum Press, New York, p. $137-170$

Goldman, J. C., Caron, D. A., Andersen, O. K., Dennett, M. R. (1985). Nutrient cycling in a microflagellate food chain: I. Nitrogen dynamics. Mar. Ecol. Prog. Ser. 24: 231-242

Goldman, J. C., Caron, D. A. (1985). Experimental studies on an omnivorous microflagellate: Implications for grazing and nutrient regeneration in the marine microbial food chain. Deep Sea Res. 32: in press

Goldman, J. C., Stanley, H. I. (1974). Relative growth of different species of marine algae in wastewater-seawater mixtures. Mar. Biol. 28: 17-25

Gude, H. (1983). Phosphorus remineralization in continuous cultures of algae, bacteria, and protozoa. Paper presented at 3rd Intl Symp. on Microbial Ecology, Michigan State Univ., August 7-12

Haas, L. W. (1982). Improved epifluorescent microscopic technique for observing planktonic micro-organisms. Annls Inst. océanogr., Paris 58 (S): 261-266

Haas, L. W., Webb, K. L. (1979). Nutritional mode of several non-pigmented microflagellates from the York River Estuary, Virginia. J. exp. mar. Biol. Ecol. 39: 125-134

Heinbokel, J. F. (1978). Studies on the functional role of tintinnids in the Southern California Bight. I. Grazing and growth rates in laboratory cultures. Mar. Biol. 47: 177-189

Javornicky, P., Prokesova, V. (1963). The influence of Protozoa and bacteria upon the oxidation of organic substances in water. Int. Revue ges. Hydrobiol. 48: 335-350

Johnson, P. W., Xu, H., Sieburth, J. McN. (1982). The utiliza- tion of chroococcoid cyanobacteria by marine protozoo plankters but not by calanoid copepods. Annls Inst. océanogr., Paris 58 (S): 297-308

Kopylov, A. I., Moiseev, E. S. (1980). Effect of colorless flagellates on the determination of bacterial production in seawater. Dokl Acad. Sci. U.S.S.R., Biol. Sec. 252: 272-274

Laacke, M., Dahle, A. B., Eberlein, K., Rein, K. (1983). A modelling approach to the interplay of carbohydrates bacteria and non-pigmented flagellates in a controlled ecosystem experiment with Skeletonema costatum. Mar. Ecol. Prog. Ser. 14: 71-79

Laws, E. A., Terry, K. L., Wickman, J., Chalup, M. S. (1983). A simple algal production system designed to utilize the flashing light effect. Biotechnol. Bioeng. 25: 2319-2335

Linley, E. A. S., Newell, R. C., Lucas, M. I. (1983). Quantitative relationships between phytoplankton, bacteria and heterotrophic microflagellates in shelf waters. Mar. Ecol. Prog. Ser. 12: 77-89

Menzel, D. W., Vaccaro, R. F. (1964). The measurement of dissolved and particulate carbon in seawater. Limnol. Oceanogr. 9: 138-142

Paasche, E., Kristiansen, S. (1982). Ammonium regeneration by microzooplankton in the Oslofjord. Mar. Biol. 69: 55-63

Pomeroy, L. R., Johannes, R. E. (1968). Occurrence and respiration of ultraplankton in the upper 500 meters of the ocean. Deep Sea Res. 15: 381-391

Raymont, J. E. G., Adams, M. N. E. (1958). Studies on the mass culture of Phaeodactylum. Limnol. Oceanogr. 3: 119-136

Rubin, H. A., Lee, J. J. (1976). Informational energy flow as an aspect of the ecological efficiency of marine ciliates. J. theor. Biol. 62: 69-91

Sharp, J. H. (1973). Total organic carbon in seawater - Comparison of measurements using persulfate oxidation and high temperature combustion. Mar. Chem. 1: 211-229

Sherr, B., Sherr, E. (1983). Enumeration of heterotrophic microprotozoa by epifluorescence microscopy. Estuar. coast. Shelf Sci. 16: 1-7

Sherr, B. F., Sherr, E. B., Berman, T. (1982). Decomposition of organic detritus: A selective role for microflagellate protozoa. Limnol. Oceanogr. 27: 765-769

Sherr, B. F., Sherr, E. B., Berman, T. (1983). Grazing, growth, and ammonium excretion rates of a heterotrophic microlagellate fed four species of bacteria. Appl. environ. Mirobiol. 45: 1196-1201

Sherr, B. F., Sherr, E. B., Newell, S. Y. (1984). Abundance and productivity of heterotrophic nanoplankton in Georgia coastal waters. J. Plankton Res. 6: 195-202

Stoecker, D., Guillard, R. R. L., Kavee, R. M. (1981). Selective predation by Favella ehrenbergii (Tintinnia) on and among dinoflagellates. Biol. Bull. mar. biol. Lab., Woods Hole 160: 136-145

Taylor, W. D., Berger, J. (1976). Growth responses of cohabiting ciliate protozoa to various prey bacteria. Can. J. Zool. 54: 1111-1114

Williams, P. J. leB. (1981). Microbial contribution to overall marine plankton metabolism: Direct measurements of respiration. Oceanologica Acta. 4: 359-364 